\title{
China's Public Diplomacy through the Utilization of Investment and Censorship in Hollywood (2012 - 2016)
}

\author{
Riski M. Baskoro ${ }^{1}$, Amalia Agustina Theresia, Anggara Raharyo \\ riskibaskoro@president.ac.id, therescia19@gmail.com, \\ anggara.raharyo@president.ac.id
}

\begin{abstract}
The conduct of traditional public diplomacy was merely concerned on the engagement of state actors. Also, diplomatic communication is only occurred between the government officials by intention to earned political changes in targeted countries. Recently, public diplomacy is mainly focused on the positive reputation building in the other country and is conducted through political and economic cooperation among two countries or more, by also involving the nonstate actors. Starting from its economic reforms' initiative, China is engaged in international trade and successfully became one of global economic powers. By its rapid raise, China is feared to be a national threat to other countries, be it politically, economically, or even for the national security. Further, the Western media often portrays China's image in a negative light. Hence, in improving its global image, China expands its global outreach by establishing cooperation with the United States film industry, Hollywood, that strengthen by the 2012's Memorandum of Understanding upon film industry, also by implementing Chinese censorship policy, where negative portrayals of China is prohibited. The conduct of censorship would be supervised under state-ruled agency, the SAPPRFT, and is supported by Chinese multinational companies' investment over Hollywood. Through this research study, the effort of China's public diplomacy on the utilization of Hollywood would be proven through new public diplomacy theory. The role of multinational corporations will also be assessed due to its essential contribution in enhancing Chinese censorship in Hollywood films for its global release.
\end{abstract}

Keywords: Bilateral Relation, China's Public Diplomacy, Film Censorship, Film Industry, Multinational Corporations

\section{Introduction}

By China's economic reforms in 1978, China's economy has increase dramatically and changes its behavior from being isolated to having an influential role towards global economy. As cited from the World Bank, China "bas experienced the fastest sustained expansion by a major economy in history - and has lifted more than 850 million people out of poverty". Even more, by having 1.3 billion populations, China became the world's second largest economy as well as the largest contributor in the global financial crisis of 2008 according to the purchasing power parity terms (World Bank, 2018). A rapid and

\footnotetext{
${ }^{1}$ Korespondensi: Riski M. Baskoro, President University, Jababeka Education Park, Jl. Ki Hajar Dewantara, RT.2/RW.4, Mekarmukti, Kec. Cikarang Utara, Bekasi, Jawa Barat 17550
} 
sustained development of China's economy has successfully caught the attention of super power state, the United States of America. Trade relation among both countries has been benefiting both sides and created economic interdependence as trading partner (Morrison, 2018).

China's film market has become one of China's economy attractions for United States as it was stated by the Motion Picture Association of America (MPAA), China box offices favorably earned profits around \$.3.6 billion (Motion Picture Association of America, 2013). It has shown China's cinema is capable to absorb a lot of audiences that automatically enlarged the earning of studio production (Hollywood). Zhang Hongsen as the Deputy Director of the State Administration of Press, Publication, Radio, Film, and Television (SAPPRFT) once appointed that China is most likely predicted to be the largest global film market in 2020 as their box office has successfully achieved about $\$ 8.36$ billion by the end of 2017 (Xinhua, 2017). Charles Rivkin as a former U.S. assistant secretary of state which currently serving as MPAA chairman said that "the Chinese film market is going to be the largest film market in short order, they are building about 25 screens a day" (South China Morning Post, 2018).

China film industry might have emerged to be the global largest film market and attracting the Hollywood. However, China still putting their local cultures as well as local industries into their priorities. Different from its country of origin - the United States that encourage creative growth of its cultural industry, Hollywood have to face censorship and quotas regulation of China's state-ruled censorship agency, the SAPPRFT, in order to grant access to its market. Even more, in order to passes its quota system, Hollywood (and/or other foreign film company) required to promote Chinese greatness and positive image in its world-wide releases by inputting Chinese cultures, hiring Chinese actors/actresses, and/or shooting the film scene(s) in China's land (Pulver, 2013). Due to a huge number of Hollywood film products that could be absorbed by Chinese market, also due to a high number of Chinese investments in Hollywood's operation, Hollywood has somehow controlled and is complying with China's protectionist regulation over foreign film. 
This study is intended to give a greater insight on how the bilateral relation in film industry between the People's Republic of China and the United States conducted, which aimed to seeking clearer and better understanding on how the China's quota and censorship regulation on foreign films with a help of numbers of Chinese outward investment towards Hollywood could be used as a new field in pursuing China's national interest and ideology. The theory as well as concept of public diplomacy and protectionism will be presented in determining the kind of relations that established between the state and non-state actors throughout the problem that occurred in this research study.

\section{Literature Review}

\section{Public Diplomacy}

Public diplomacy is a concept that has variety definitions by scholars and politicians. The difference in defining the term occurred by a different set of perspective and interest of an individual, it also can be influenced by different set of values and a changing situation that happened in a country (Szondi, 2008). According to Joseph Nye, public diplomacy is a key instrument that can be used to activate soft power, and is can be explained as a government's tool to communicate and engage with international audiences (Nye, 2004). Nye also said that public diplomacy used as state efforts to earned respect and sympathy from other nation, to give them a portrayal of their nation ideals, goals, policies, cultures and society in establishing a positive image and relations (Kayani \& Rehman, 2015).

In 1965, Edmund A. Gullion as the former Dean of the Fletcher School defined public diplomacy as,

"Public diplomacy deals with the influence of public attitudes on the formation and execution of foreign policies. It encompasses dimensions of international relations beyond traditional diplomacy; the cultivation by governments of public opinion in other countries; the interaction of private groups and interests in one country with those of another; the reporting of foreign affairs and its impact on policy; communication between those whose job is communication, as between diplomats and foreign correspondents; and the processes of inter-cultural communications. Central to Public Diplomacy (PD) is the transnational flow of information and ideas" (Cull, 2006). 
Alan K. Henrikson as a Professor of Diplomatic History once defined public diplomacy as government efforts in establishing a relation with other government through the media and by involving the non-governmental parties (e.g. political parties, educational institutions, private enterprises, etc.) (Kayani \& Rehman, 2015).

In this research of study, the term of public diplomacy was used in order to determine the relations between United States and China within film industry. Strong involvements of government and MNCs within entertainment industry that pursue national interest have somehow considered the relation as the realization of the 'new' public diplomacy concept. The 'new' public diplomacy emphasizes the importance of relations and engagements than only to influences the audience overseas. 'New' public diplomacy is not only a tool of one country to communicate with foreign countries but also to engage with the local audiences, its own citizen (Melissen, 2005). The citizen should be well informed by their country's foreign policy in order to create a progovernment environment and the citizen is expected to promote its own nation interest (Malone, 1985). By that, the citizen will be felt more involve in pursuing the nation objectives as they are becoming a part of the foreign policy strategy itself. The public diplomacy is shifted from achieving behavioral goals to attitudinal/cognitive goals, from one way to two way of communications, persuasion to relationship building, also from only managing to engage with publics (Szondi, 2008).

Supported the idea of 'new' public diplomacy by Jen Melissen, the concept of Brian Hocking is being more persuasive to the authoritarian and/or state-based country to practice the 'new' public diplomacy. According to Hocking's concept, there are two models of public diplomacy, which are; the hierarchical model and the network model. The hierarchical one is a model where a state-centered government placed its control upon its public diplomacy instrument. Any international interaction would be under the watched of the government so it could have an expected result. Meanwhile, the network model is expecting the engagement of the non-state actors - e.g. Multinational Corporations (MNCs) and Non-Governmental Organizations (NGOs) in international interaction. Hocking argued that a 'new' public diplomacy is a mixture of 
models between those two, whereas it can be used as a platform that engaging both state and non-state actor's role in pursuing the same objectives (Hocking, 2005).

\section{Protectionism}

Gowling WLG once said, Protectionism is complex and can be viewed positively or negatively depending on the country and market a business operates in' (Kirk, 2017). It is happened in a form of high tariffs, restrictive quotas, and any other regulation that could discourage import activities. Such action was taken so that the government can protect their people in a form of local business, local beliefs, local cultures, and others (Fouda, 2012). The protectionism can be determined by two factors, which are trade restrictiveness and discrimination towards foreign economy (Kommerskollegium, 2016). Protectionism policy was created to improve sand benefits their local enterprises within its border, the benefit is intended to cover the owner, workers, and suppliers of the protected industry (Coughlin, Chrsytal, \& Wood, 1988). Moreover, in the free trade market of cultural products, the protectionists are intended to protect their nation from any Americanization or commercialization.

The conduct of international trade is requiring states to open its border more in order to create a harmonious cooperation among them. Several agreements were produced by international institutions such as the United Nations (UN), World Bank, the General Agreement on Tariffs and Trade (GATT), and more, with an aim to support the effectiveness of international trade. However, with different national regulatory priorities, problems within the liberalization of international trade started to rise (Runge, 1990). Not only implies the tariff increases which is transparent and easy to be measured, many protectionist countries utilized the non-tariff barriers where the conduct of restrictiveness towards foreign competitors is much more hidden (Southern African Development Community. Non-tariff barriers reflected in a policy instruments that covers the implementation of quotas, bans and/or licensing requirements. Such actions were often used by the high-income countries or the more developed country according to its economy sector (Yalcin, Felbermayr, \& Kinzius, 2017). 
In addition, the behavior of the protectionist country could also be presented in the term of domestic standard and/or market-based standard. This research study will analyze China's protectionist decision in activating censorship regulation in order to protect its citizen from overseas influence through films. Protectionism occurs in a form of market-based standard when "the welfare-maximizing domestic standard is higher than the international standard maximizing welfare inclusive of foreign profits" (Marette \& Beghin, 2007). Market-based standard has allowed foreign and local enterprises to compete in domestic market where its consumers were attached to one particular standard. The standard is most likely be regulated by the government in order to protect their internal society from any safety and environmental concerns.

Domestic standard requiring countries to submit the sample of the product before it was produced for its market and is requiring a certification or license of production process in order to granted access to its market. Not forget to mention, the designation of the product would be limited and controlled by the market - or often being represented by the government, in order to meet the standard (Marette \& Beghin, 2007). As the term of national product standard started to emerge and arise in the international trading system, the tension between countries also seems to be increased. With the existence of non-tariff barriers along with domestic standard, the trading system will surely be reduced as countries could not do its import-export activities due to the protectionism behavior which adopted by some developed countries (Sturm, 2006).

\section{Methods}

This research study is designed as descriptive research with qualitative method which focusing on fact-finding inquiry. It utilizes the data of movie production that is invested by China for the investment part and Chinese policy on the censorship of movies. The main subject of this research is China's censorship policy and agency that controlling the operation of Hollywood as it could not portray China in negative lights, especially with the existence of Chinese investment over Hollywood that enhances the utilization of their censorship policy. The period of time of the research would be 
limited to the year of 2012 until 2016, as the mutual agreement upon film industry between the United States and China is established in 2012 and the problem started to become the center of the United States Congress focus in 2016. Also, in between 2012 and 2016, numbers of Hollywood films were supported by China's investment that resulting China's censorship in charged for the film's international releases.

\section{Result and Discussion}

\section{Bilateral Relations between China and the United States within Film Industry}

During China's cinematic history, Hollywood continuously improving its film production in order to be fitted in the Chinese local market and is resulting a high demand from the local citizen as well as local filmmakers (Yang, 2018). Shanghai as the birthplace of Chinese cinema which later be acknowledged as the largest market share in history has played multiple of Hollywood films since the beginning of 1920s. China's film industry was swiftly rise by importing the Hollywood films as it seen by the growth of their cinema numbers from around 100 cinemas in 1927 to 250 in 1930 (Wang T. , 2007). The control over China's film markets is fully owned by the United States as later they got de facto monopoly that covers China's film distribution and exhibition sectors in the late 1920s (Zhu, 1998).

Hollywood domination over Chinese film industry back then was recognized as United States official efforts to promote its industrial trade as well as their ideology in China, it was stated that "...through the motion-picture film there can be impressed upon the Chinese methods, ideas, and materials of an essentially American character" (North, 1927). The domination was started in 1933, where 431 foreign feature films being imported to China's land, with 355 of them being imported from the United States, which thus accounted for $82 \%$ of the total. During 1934, $85 \%$ of China's imported films were American films with the total number of 345. Lastly, in 1936, the percentage was increased to $89 \%$ of the total of China's film imports though the number was decreased with 328 films only (Chaoguang, 1998/1999). 
Engaged in an up and down relationship within film industry since 1890, and Hollywood even once banned in China due to Korean War 1950, the United States continuously finding ways to strengthening its film industry cooperation with China, especially as China's film market becoming the world's largest one. Having numbers of barriers upon foreign cultural products and is being very sensitive towards ideology and nationality content of foreign film, China's film industry would always find its way to returns to Hollywood. Hollywood studios have brought Chinese audiences' expectation to another stage of level as the studio has served each film with a highly-developed technique. Secondly, neither quality nor quantity of China's film could meet their market expectation, which has led China to import Hollywood films in revenue-sharing (Amdur, 1996).

China's decision to import Hollywood films has brought American film expertise to China which may speed the sophistication of economic mechanisms in the Chinese film market. However, as China's film industry relies upon Hollywood film production for profits, they come into realization that westernization would also be happened and would endanger their ideology by such decision. Therefore, China started to produce protectionist move by having censorship agency as well as regulations that created problems for foreign film studios especially Hollywood. Though it is hard to grant an access to Chinese market due to censorship issues, Hollywood kept on putting efforts as Chinese film market will produce high earnings for them. Thus, the 2012's Memorandum of Understanding $(\mathrm{MoU})$ on film market access was established between the United States and China in order to strengthen their cooperation as well as give a better access for American films in Chinese market.

\section{China's Censorship Policy and Its Influences on Hollywood Films}

Based on China's historical background, specifically in the early Communist era, film was considered as a propaganda tool and is fully controlled by the Communist Party. Hollywood and Hong Kong film productions were banned as the local production started to be encouraged more by the government to serve political objectives of the Communist Party. The local film production was focusing on Chinese soldiers and 
workers as the theme of the film, such as Bridge (1949) and The White Haired Girl (1950) (Xiao, 2013). In the establishment of the People's Republic of China in 1949, the regulations over motion pictures and any other form of mass media was controlled tightly by the government as the existence of mass media was perceived as a great platform to do propaganda (Xu, 2017). Thus, Chinese film censorship is aimed to filtering and banning films before it is produced or released with several requirements that should serves the criteria of the Party - including its content, its actors, the film plots and other elements (Bai, 2013).

In performing the censorship system, several institutions have been established by the government from time to time in order to achieve a satisfactory result. In 1931, the National Film Censorship Committee (NFCC) was established by the Ministry of Interior and Education along with the Publicity Department of the Central Committee of the CCP (CCPPD) to regulate the film censorship. In 1986, the Ministry of Culture, the Film Bureau, and the Department of Radio and Television were merged into the establishment of Ministry of Radio, Film and Television (MRFT) (Geltzer, 2017). The MRFT was expected to have a stricter control and management by strengthening the supervision on film production (Lixiao, 2004). On 25 June 1998, the MRFT was then modified into the State Administration of Radio, Film and Television (SARFT) (Wu I., 2009). The SARFT is existed to operate and determine the equipment standards of all instruments under the agency. In addition, it also created to ensure all of the published content is suitable and will not harm the audiences (Global Edge, 2003).

The authority and responsibility of SARFT later be incorporated with the General Administration of Press and Publication and resulted the establishment of the State Administration of Press, Publication, Radio, Film and Television (SAPPRFT) in March 2013 (Tartaglione, 2013). Not so different with its formers, the SAPPRFT was formed with aimed to ensure and maintain the released film in China is fulfilling the requirements, be it the local or foreign production (Geltzer, 2017). The decentralized authority of SAPPRFT is officially stated on the Film Industry Promotion Law as the first national of China's film industry that has been released on 7 November 2016. 
By the existence of the SAPPRFT, foreign film must be China-free in order to be imported to its market, which means the film must not disgrace Chinese cultures, believes, ideology, or just China's image in general. It also must not contain sexuality, violence, supernatural creatures and nudity as it is feared to harm Chinese perspective and lifestyle (Busch, 2016). Hollywood motion pictures' ability to attract audiences is undeniably powerful. The way they put the advanced film technology, the story-lines and the actors' arrangement has successfully delivered what an American dream is and never failed to put its audiences in adoration. Further, the United States is a liberal state where the (mentioned) forbidden contents in China are totally allowed in American film production, which in this case is produced by Hollywood. Therefore, if Hollywood wished to entering China's film market in order to gain high profits, it is must obey China's censorship regulations, which reflected by the following examples.

\section{a. Red Dawn (2012)}

Red Dawn was first scripted to put China as the opposition, the issue travelled fast as it quickly rises by Chinese media and heard by Chinese officials. Feared of losing its billion-worth market, Hollywood studios, which in this case was the MGM, is settled to replaces villain position from China to North Koreans (Hughes, 2012).

"Despite the world's focus on U.S.-China relations in the Strategic and Economic Dialogue and their increasing economic connections, China can still feel U.S. distrust and fear, especially among its people. Americans' suspicions about China are the best ground for the Hawks to disseminate fear and doubt, which is the biggest concern with the movie 'Red Dawn" (Landreth, 2010).

As it has been shown in Picture 1, MGM studio was decided to digitally change the film's visual appearance from China's attributes to North Korea ones and was spent about US\$1 million to replace the issue (Qin \& Carlsen, 2018). 
Picture 1. MGM digitally change Red Dawn Scenes from China (right) to North Korea (left)
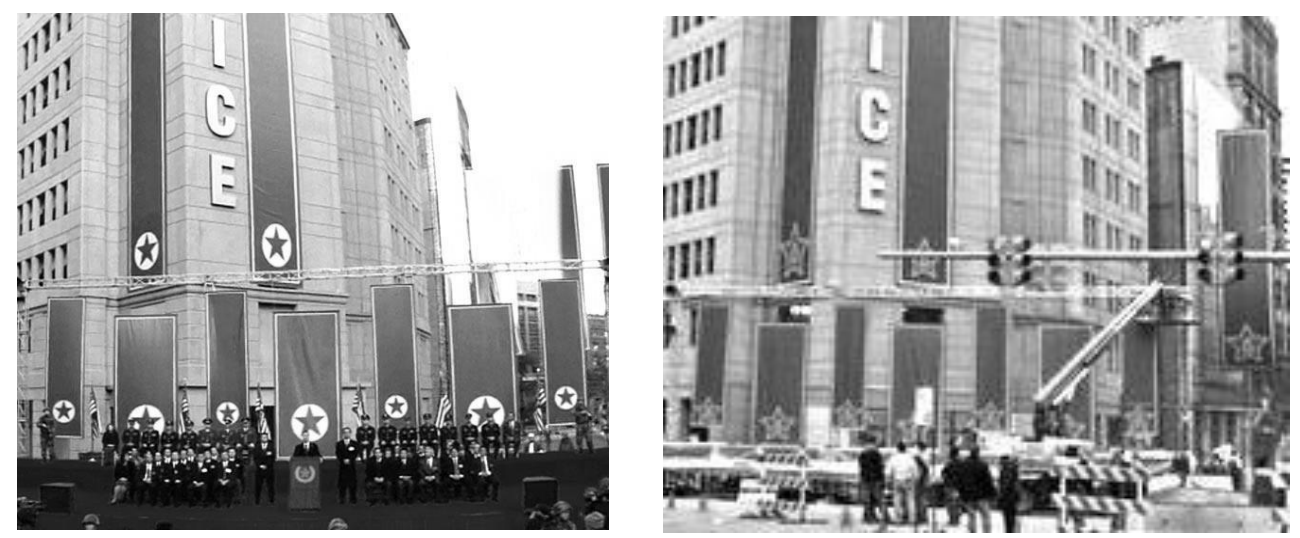

Source: (Qin \& Carlsen, 2018).

\section{b. Iron Man 3 (2013)}

Co-produced by China’s DMG Entertainment Group, Iron Man 3 became the biggest blockbuster in China's cinema throughout 2013, and is drawing many attentions by people overseas due its differences with Iron Man 3 version in other country's big screens (Daniel, 2013a). China's version of Iron Man 3 has an additional four minutes scene and is having an advertisement of Chinese milk product named Gu Li Duo that mentioned Iron Man's source of energy (Chilton, 2013).

Picture 2. Additional footage of Iron Man 3's Chinese version

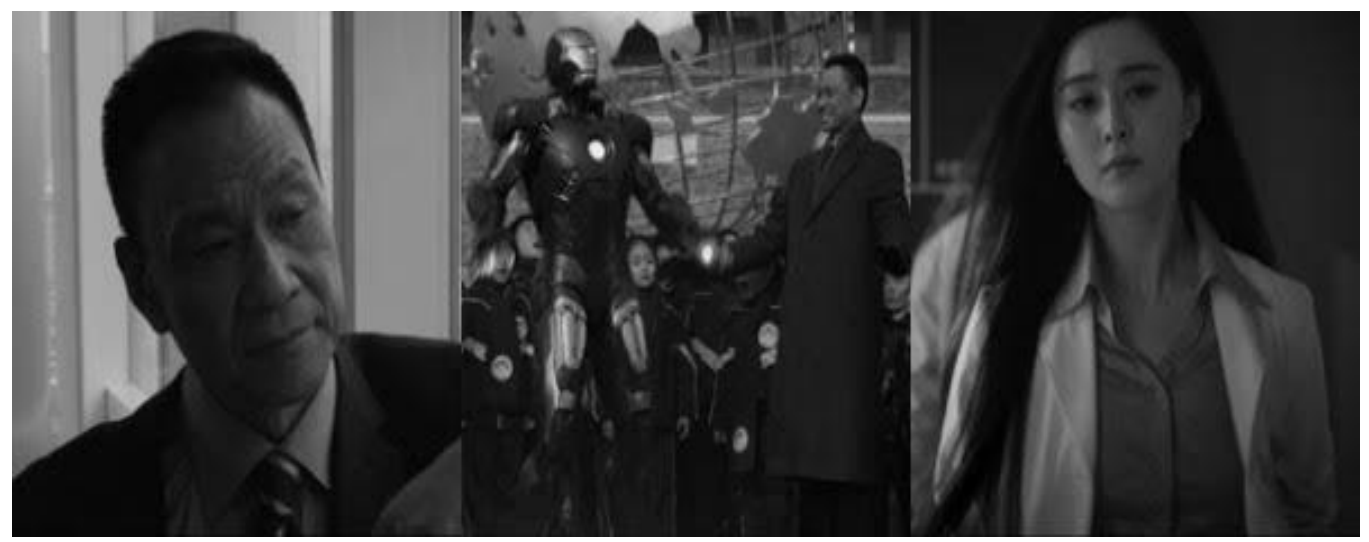

Source: (Trumbore, 2013). 
As described in Picture 2, the additional footage was exclusively presented to its Chinese audiences as it was viewed in Chinese language and starring by two Chinese leading actors Wang Xueqi as Dr. Wu) and Fan Bingbing (as Dr. Wu's assistant) (Daniel, 2013b).

Before its release, Walt Disney allows the Chinese censors representative to examine the scripts and to join their shooting process in the United States, also their critics and suggestions of the film content were welcomed. Some of Iron Man 3's scenes were shot in Beijing by the director Shane Black (Daniel, 2013a). Not only having an additional footage and new actors, the villain figure in this film which was 'the Mandarin' was also changed to be 'Man Daren' by Chinese censors officials (Wan, 2013). All of the changes were pursued to fulfill China's coproduction procedural that oblige co-produced films to be shot in China, involved Chinese actors, and describe any positive image of Chinese elements (Brzeski, 2012).

\section{c. Pixels (2015)}

Produced by Sony Pictures Entertainment and co-financed by Alibaba Pictures and China Film Group Corporation, Pixels was originally scripted to have a scene where aliens were plotted to attack the Great Wall of China. However, in its final version in Picture 3, the aliens were viewed to bash other world's monuments which are the Washington Monuments, the India's Taj Mahal and some parts of Manhattan (Baldwin \& Cooke, 2015). The motives behind the changes was soon exposed by WikiLeaks - an international non-profit organization that reveal secret document and information, in a form of private emails from Li Chow as the chief representative of Sony Pictures in China to Sony's senior executives.

"Even though breaking a bole on the Great Wall may not be a problem as long as it is part of a worldwide phenomenon, it is actually unnecessary because it will not benefit the China release at all. I would then, recommend not to do it. As to relocating the Pac-Man action from Tokyo to Shanghai, this is not a good idea because it will involve destruction all over the city and may likely cause some sensitivity" (WikiLeaks, 2013). 
Picture 3. Pixels plot: Aliens attack in the Washington Monument and the Taj

Mahal

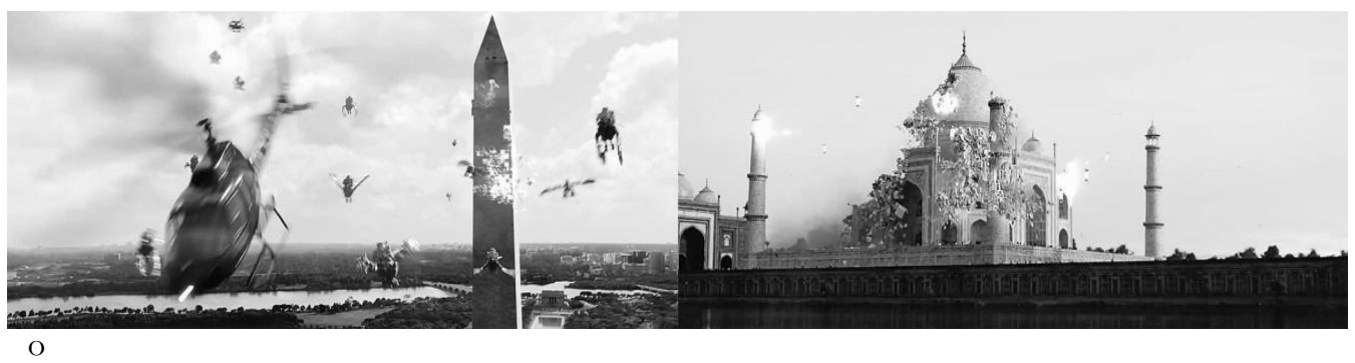

Source: (Baldwin \& Cooke, 2015)

\section{China's Outward Direct Investment in Enhancing China's Censorship Policy in Hollywood}

By work jointly with the Chinese companies, Hollywood will have a broader chance to enter Chinese film market as the procedural of the co-production that was arranged by the China Film Co-Production Corporation (CFCC) under the China Film Group Corporation (China Film), also supervised by the SAPPRFT. Further, Chinese censorship policy is required foreign film to have a minimum one-third Chinese investment from its total investment will be passed with the co-production on the line (O'Connor \& Armstrong, 2015). Dalian Wanda Group altogether with Baidu Inc., Alibaba Group, and Tencent Holding Limited (BAT) are four gigantic Chinese enterprises that engaged in China-U.S. film industry's cooperation.

"Chinese companies feel they have not brought storytelling to life in a way that has appeal to both Chinese audiences and, they hope, global audiences. So they look to the West; Hollywood has created these robust films and companies that have rich, deep libraries of content." -Tom Connolly of EY global media (Frater, 2015).

Dalian Wanda Group Co, Ltd. is one of China's successful MNCs that is recognized world-wide in many sectors including entertainment ones. Dalian Wanda started to be a center of attention as it placed the US\$ 2.6 billion of $75 \%$ acquisition on the AMC (American Multi-Cinema) Entertainment Holding, Inc., the second-largest North American movie house chain (Nunlist, 2016). The deals has reflects tighter relations between China and the United States within film industry that has been opened 
since February 2012 (Jones \& Thomas, 2012). In September 2013, the Academy of Motion Picture Arts and Sciences (AMPAS) announced the gift of US\$300 million from capital campaign for the Academy Museum. Later in 2016, Dalian Wanda purchases Legendary Entertainment's stake for US\$ 3.5 billion which positioned Dalian Wanda as one of the leading global players in film production (BBC News, 2016). According to Stanley Rosen as a USC political science professor and Chinese film expert, the deal was "...feeding into what the Chinese government wants to hear, that Wanda is doing this for patriotic reasons, in a sense, and to promote China as a global player" (Kaiman \& Meyers, 2016).

The large amount of China's investments across the Hollywood was considered aggressive by the Washington. Dalian Wanda ambition to rule the global film industry, especially Hollywood, has attracts the attention of the federal government, which later agreed by the Government Accountability Office (GAO) to determine whether the Committee on Foreign Investment in the United States (CFIUS) efforts "bave kept pace with the growing scope of foreign acquisitions in important economic sectors in the United States" (Liu L., 2016). Dalian Wanda's rapid purchase over Hollywood's stake started from 2012 until 2016 has raised concerns among the United States Congress and is create confusion within its lawmakers upon Dalian Wanda intention in buying the ownership.

It is should be noted that Chinese government will constantly be involved in all of economic activity including China's investment (Moore, 2017). It exactly the reason why all of the 16 members of the Congress assumed that Wanda group's investment could threaten its national security by employing Chinese "efforts to censor topics and exert propaganda controls on American media" (Lang \& Maddaus, 2016). The condition has complicated the relations between Hollywood studios and Chinese film production companies.

\section{Public Diplomacy Efforts through China's Censorship and Outward Direct Investment towards Hollywood Studios and Films}

China's public diplomacy is invested to achieve the China's foreign policy objectives and its domestic development. As one's image is matter in its future 
development, both China's government and scholars perceived that China is need to be engaged in global audiences as its image has been assumed manipulated and disgraced by the Western media (d'Hooghe, 2015). According to d'Hooghe, the objectives of China's public diplomacy can be breaking down into four sub-goals. Firstly, it is supposed to describe China as a great global economic partner that does not need to be feared by its current rise since China is promoting a 'peaceful rise'.

Secondly, promoting itself as a 'barmonious world', China is intended to be seen as a country that enhanced international security and favored international peace. The third objective is to make the other countries understood that China is building towards a barmonious society' where it expects the country's growth without sacrificing the people needs. Lastly, China aimed to promote its culture to be globally acknowledged and respected. Additionally, according to Jia Qinggo, China's public diplomacy could also be used to find its identity, as he said that "the aim of conducting public diplomacy is not only to strengthen other countries' understanding of China, but also to strengthen our own understanding” (d'Hooghe, 2010).

Nevertheless, China is receiving a lot of negative views that was summarized and named as the China Threat Theory, which separated into three main ideas that shows a complete opposite result with China's public diplomacy objectives. First, China was perceived as a political and ideological threat with its human rights issue background. Second, instead of being viewed as a harmonious country, China is recognized more as a military threat as seen by its aggressive effort in developing and investing its military sectors. Lastly, by having a cheaper cost of goods and workers, China was blamed for job losses in another part of the world and is anticipated as economic threat by its economy rise (Hartig, 2016).

Another obstacle in constructing China's positive image has been pointed out by Yiwei Wang, which it needs to compete with the Western hegemonic discourse (Wang Y. , 2014).

"China faces hegemony of discourse, since most of the world's news is expressed within the framework of Western concepts and ideology and dominated by the English-language media. 
China enjoys economic and cultural power, but it cannot control how it is portrayed in the

Western media" (Wang Y., 2008, p. 265).

Public diplomacy is purposely created to eradicate the misinterpretation and misunderstanding globally. However, language and cultural gap has created a burden for China to express their intention. For instance, Chinese popular terms such as peaceful rise and harmonious world has leave huge ambiguity to the global audiences as those words alone can be defined and interpreted in so many ways (Wang Y., 2008).

Therefore, as advised by Li Changchun as China's Politburo Standing Committee, international expansion of mass media outreach should be projected in order to engage Chinese local media with global community (Bandurski, 2009). Positively responded by the government, in the early of 2014 until 2016, China have spent approximately US\$ 5 billion of investment in the United States film industry operational in general and another million on the specific film production ( $\mathrm{Ng}, 2016)$. Such investment and cooperation was taken because, no matter how great the Chinese cultures and values are, China still have lacking of cultural power that attracting and impacting enough for the world (d'Hooghe, 2015).

Some scholars and practitioner analyzed that China does not have the ability to transliterate its vision into a cultural product that was favored by global audiences. For instance, the film of Mulan and Kung Fu Panda successfully entered the world's box offices that portrayed Chinese cultures, however, those films were produced by Hollywood instead of Chinese film companies. Therefore, China is hardly exporting its cultural product and is still continuously imports foreign cultural products in order to fulfill Chinese entertainment consumption (d'Hooghe, 2015).

China's censorship regulation has been requiring Hollywood not to portray China's negativity. The problem is that Chinese censorship over Hollywood films will not only be applied for China's release, but also for world-wide release with a help of Chinese investment all over Hollywood. China Business Review once claimed that the world does not need to be concerned upon the growing issue that saying Chinese censorship and huge outward investment towards Hollywood will becomes their new 
public diplomacy platform. It was because the censored film will only be screened for Chinese cinema, instead of for the world-wide releases, while public diplomacy is supposedly targeting the foreign publics $(\mathrm{Ng}, 2016)$.

In fact, according to the 'new' public diplomacy concept by Jen Melissen, public affairs activities - dealing with domestic citizens, should not be separated with public diplomacy efforts. Seeing by globalization, every individual around the world is interconnected to each other. Logically, through advanced communication technology, the information that being published within the border is could also be reached by people overseas, and so does the other way around (Melissen, 2005). Protecting domestic audiences will create mutual understanding in between the government and citizen, also will engage them in one vision. Further, as stated before, the existence of Chinese investment in Hollywood will also enhance the utilization of Chinese censorship in every film production that will reflect the Party's interest because the local enterprises were mainly state-ruled or state-owned.

Additionally, due to profits-seeking reason, Hollywood has done selfcensoring for every single of its film products in order to obtain access to China's market. Self-censoring has caught the attention of Barack Obama by saying,

"If somebody is able to intimidate folks out of releasing a satirical movie, imagine what they start doing when they see a documentary that they don't like, or news reports that they don't like. Or even worse, imagine if producers and distributors and others start engaging in self-censorship because they don't want to offend the sensibilities of somebody whose sensibilities probably need to be offended. That's not who we are. That's not what America is about" - Barack Obama at his year-end White House press briefing (Baldwin \& Cooke, 2015).

Even more, the United States Congress views the censorship and investment as their national threat. However, those concern seems being neglected by Hollywood studios as once Christoper Dodd as former chief executive of the Motion Picture Association of America (MPAA) said, "If you ask these guys what their three major goals are, they will tell you China, China, China” (Barnes, 2017).

Through this research study, Chinese censorship and investment were proven to be a part of Chinese public diplomacy efforts by refers to the theory of 'new' public diplomacy. First, new public diplomacy theory requires to not viewing public 
diplomacy effort as a unique and different activity of a state, simply it should not be obvious. Instead, the effort must be done through the practice of state in general (Melissen, 2005, p. 12) Unlike the Panda diplomacy that officially stated as a part of Chinese public diplomacy, the practice of public diplomacy through censorship and investment regulation is a part of Chinese economy practices and had been done explicitly. The establishment of censorship itself has come as China's effort to protecting its film industry in facing Hollywood's economic domination, which required a strong nationalistic to do so (Xiao, 2013).

Second, as stated before, the public diplomacy effort must be aligned with public affairs practices because "engaging with one's own domestic constituency with a view to foreign policy development and external identity-building has become part of the public diplomacy strategy" (Melissen, 2005, p. 13). Thirdly, public diplomacy must be done through a dialogue with a targeted country. A condition whereas it requiring two way of communication. The practice of Chinese censorship and investment could not be done without the participation of Hollywood film production companies. The film production that accordingly refers to Chinese censorship was carried out in a conscious state with an agreement tied among them, which means there is no enforcement by doing so. It is purely being carried out since Hollywood studios desperately need to enter China's film market and Chinese film enterprises need to be acknowledged globally. Two way of communication is also reflected in the practice of bilateral relations that covers political dialogue, trade and foreign investment. Particularly, bilateral relation is where the Chinese censorship and outward investment come into operation (Melissen, 2005, p. 14)

Lastly, the term of 'new' public diplomacy is also promoted by Brian Hocking. According to his argument on 'new' public diplomacy theory, China was still considered to follow-through the national diplomatic system in maintaining its public diplomacy efforts. By reason of, China's diplomatic instruments were placed under the government bureaucratic so any international interactions could be monitored by them. Its international policy was used as gatekeepers of its overseas activities, in which it was also the function of Chinese censorship itself. Not to mention, the outward investments 
that were done by Chinese MNCs are supervised by the SAPPRFT and the CFCC as state-ruled agencies. The involvement of MNCs itself was urged by Hocking's view as the improvement of China's traditional diplomacy to the practice of public diplomacy (Hocking, 2005).

\section{Conclusion}

Censorship policy was equal with government expectation towards local and foreign film that would be released in China. Started from 1979, Chinese government was agreed to acknowledge its cinema as state-funded cultural institution that could be utilized to transmit and deliver China's heritage and ideology. Hence, any film that would be screened in China must portrays China's positivity and must not harmed the perspective and believe of Chinese audiences. China's box offices were massively growing with the earnings of US\$ 3.6 billion in 2013, US\$ 6.6 billion per 2016 and US\$ 8.36 billion by the end of 2017, and even projected by the SAPPRFT to surpassing the United States as the world's largest film market by 2020. Therefore, even though China's censorship policy was so strict, Hollywood studios still being so competitive in producing films to enter the Chinese billion dollars' worth market.

During 2012 until 2016, Chinese multinational conglomerates were actively placed a high number of outward investments in Hollywood studios and co-financed its film project for international releases. The motives behind Chinese MNCs outward investment towards Hollywood studios were identified as its effort in learning advanced technology in film production, also in gaining international acknowledgement. However, it has built an assumption of other motives behind and is raises concern among the United States Congress members as it was delivered through a letter directed to the Government Accountability Office (GAO). According to the Congress, Dalian Wanda's acquisition towards major Hollywood studios and American cinema chains were feared to be a part of China's effort in censoring content and exerting ideology controls upon American media. 
Based on the analysis of this research study, China's censorship and outward investment towards Hollywood studios and film projects are counted as China's public diplomacy efforts. Even though China's censorship was actually designed for international film that intended to enter China's market, with the helped of China's huge amount of investment in Hollywood, China's censorship was taking control of Hollywood film production that prepared for its international releases. Also, the tool of China's public diplomacy could not fulfill nor deliver China's interest to the world. Thus, China needs a strong platform that was consumed and understood by global audiences in order to promote their ideology, culture, heritage, characteristic and values. Hollywood's popularity among citizens in every country has the ability to transliterate China's vision into cultural products that were favored by international audiences. Also, with China's investment, the official got a privilege to use Hollywood as their public diplomacy tools through the enhancement of censorship.

\section{Bibliography}

\section{Books}

d'Hooghe, I. (2010). The Expansion of China's Public Diplomacy System. In J. Wang, Soft Power in China: Public Diplomacy through Communication (pp. 19-35). New York: Palgrave Macmillan.

Melissen, J. (2005). The New Public Diplomacy: Between Theory and Practice. In J. Melissen, The New Public Diplomacy: Soft Power in International Relations (pp. 323). Basingstoke: Palgrave Macmillan.

Xiao, Z. (2013). Prohibition, Politics, and Nation-Building: A History of Film Censorship in China. In D. B. Winkel, Silencing Cinema: Film Censorship around the World (pp. 109-130). New York: Palgrave Macmillan.

\section{Journal}

Wang, Y. (2008). Public Diplomacy and the Rise of Chinese Soft Power. The Annals of American Academy, 257-273. 


\section{Government/Official Website}

Library of Congress. (2017, February 28). China: First Law on Film Industry Effective in March. Retrieved from The Law Library of Congress: http://www.loc.gov/law/foreign-news/article/china-first-law-on-filmindustry-effective-in-march/

World Bank. (2018, September 16). Where We Work: The World Bank In China. Retrieved from Overview: http://www.worldbank.org/en/country/china/overview

\section{Online Article}

Baldwin, C., \& Cooke, K. (2015, July 24). How Sony sanitized the new Adam Sandler movie to please Chinese censors. Retrieved from Reuters: https://www.reuters.com/investigates/special-report/china-film/

Barnes, B. (2017, April 28). Christopher Dodd to Step Down as Top Lobbyist for Movie Industry. Retrieved from New York Times: https://www.nytimes.com/2017/04/28/business/media/chris-doddresign-mpaa.html

Cull, N. J. (2006, April 18). "Public Diplomacy" Before Gullion: The Evolution of a Phrase.

Retrieved from USC Center on Public Diplomacy: https://www.uscpublicdiplomacy.org/blog/public-diplomacy-gullionevolution-phrase

Frater, P. (2015, February 3). China Rising: How Four Giants Are Revolutionizing the Film Industry. Retrieved from Variety: https://variety.com/2015/film/asia/chinarising-quartet-of-middle-kingdom-conglomerates-revolutionizing-chinesefilm-industry-1201421685/

Kirk, A. (2017, November 28). Mapped: Protectionism is on the rise as US and EU implement thousands of restrictive trade measures. Retrieved from The Telegraph: https://www.telegraph.co.uk/business/2017/11/28/mappedprotectionism-rise-us-eu-implement-thousands-restrictive/ 
Landreth, J. (2010, June 1). Chinese press rails against 'Red Dawn'. Retrieved from The Hollywood Reporter: https://www.hollywoodreporter.com/news/chinesepress-rails-red-dawn-24152

Lang, B., \& Maddaus, G. (2016, September 22). Lawmakers Raise Questions About Chinese Investment in Hollywood. Retrieved from Variety: https://variety.com/2016/film/news/wanda-lawmakers-raise-questionsabout-chinese-investment-in-hollywood-1201868250/

Liu, L. (2016, October 19). Washington is taking a hard look at China's aggressive investment into US entertainment. Retrieved from Business Insider : https://www.businessinsider.sg/washington-takes-hard-look-at-chinasinvestment-into-us-entertainment-2016-10/?r=US\&IR=T

Marette, S., \& Beghin, J. C. (2007). Are Standards Always Protectionist? Iowa: Center for Agricultural and Rural Development Iowa State University.

South China Morning Post. (2018, April 5). Hollywood says China will soon be world's top film market, as ticket sales overtake US-Canada in 2018. Retrieved from South China Morning Post: https://www.scmp.com/culture/filmtv/article/2140381/china-will-soon-be-worlds-top-film-market-havingovertaken-us-canada

WikiLeaks. (2013, December 18). Sony - Re: Pixels China. Retrieved from WikiLeaks: https://wikileaks.org/sony/emails/emailid/189623 